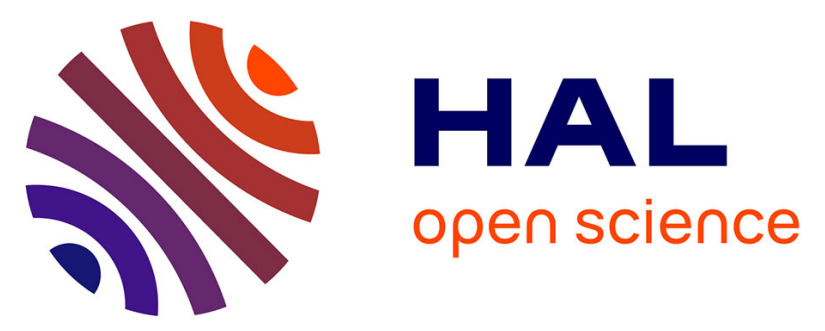

\title{
What Affect Manufacturers Approaching Servitization: A Case Study in HVAC Industry
}

Claudio Sassanelli, Giuditta Pezzotta, Fabiana Pirola, Sergio Terzi

\section{To cite this version:}

Claudio Sassanelli, Giuditta Pezzotta, Fabiana Pirola, Sergio Terzi. What Affect Manufacturers Approaching Servitization: A Case Study in HVAC Industry. 15th IFIP International Conference on Product Lifecycle Management (PLM), Jul 2018, Turin, Italy. pp.400-409, 10.1007/978-3-030-01614-

2_37. hal-02075561

\author{
HAL Id: hal-02075561 \\ https://hal.inria.fr/hal-02075561
}

Submitted on 21 Mar 2019

HAL is a multi-disciplinary open access archive for the deposit and dissemination of scientific research documents, whether they are published or not. The documents may come from teaching and research institutions in France or abroad, or from public or private research centers.
L'archive ouverte pluridisciplinaire HAL, est destinée au dépôt et à la diffusion de documents scientifiques de niveau recherche, publiés ou non, émanant des établissements d'enseignement et de recherche français ou étrangers, des laboratoires publics ou privés. 


\title{
What affect manufacturers approaching servitization: a case study in HVAC industry
}

\author{
Claudio Sassanelli ${ }^{*}$, Giuditta Pezzotta ${ }^{2}$, Fabiana Pirola $^{2}$, Sergio Terzi ${ }^{1}$ \\ ${ }^{1}$ Politecnico di Milano, Department of Management, Economics and Industrial \\ Engineering, Via R. Lambruschini 4/b, 20156, Milano, Italy \\ claudio.sassanelli@polimi.it, sergio.terzi@polimi.it \\ ${ }^{2}$ University of Bergamo, Department of Management, Information and Production Engi- \\ neering, Viale Marconi, 5, Dalmine (BG), 24044, Italy \\ giuditta.pezzotta@unibg.it, fabiana.pirola@unibg.it
}

\begin{abstract}
Product Service System (PSS) development involves both manufacturing and service workers, carrying them great potential to pursue industrial competitiveness, customer satisfaction and sustainable improvement. The belief is that the development level of PSS design is slowly evolving through a path strongly driven by the evolution of the technology and the progressive involvement of the industry in its application. However, on one side some companies still need to understand the relevance of the development process related to their service offer, on the other best practices able to improve the PSS development processes performances more systematically are needed. The paper proposes a case study, first providing a mapping of the service offer of Company A, an Italian company in the humidifiers industry. Then, it investigates, through a content analysis, what could affect companies both positively or negatively to switch their approach from a product-centric to a service integrated one. This transition would enable them in the future to develop more advanced PSSs, opening new market opportunities and being more capable of satisfying customer needs.
\end{abstract}

Keywords: Product Service System (PSS), Product Service System Development, Servitization, Case study, Humidifiers industry

\section{Introduction}

The manufacturing world, increasingly absorbed by Service Economy [1], [2], has today to cope with the need of navigating the "servitization" phenomenon [3]. To do this, companies are compelled to change their traditional business model, based on the development and sale of pure product, in a Product-Service System (PSS) based one, where new services are added and bundled to physical products [4]. However, due to the high complexity of this process, this transition is slow and gradual [5], [6] and composed of several sequential and parallel steps [7]. Indeed, it requires companies not only to raise their awareness and capacity of consistently designing combined products and 
services but also to plan other changes inside and outside themselves, as the type of relationship with customers, the cash flows dynamics and the business costs and risks [8]. Indeed, in order to adequately act on these different dimensions, new PSS customized business models are needed, enabling manufacturers to go through this gradual "service infusion" [8]-[10], [11] and to fulfil customer-focused value creation, long-lasting productions [12] and sustainable consumption patterns [13].

Thus, this paper aims at understanding what could affect companies along with their transition from a product-centric approach to a service integrated one. To do this, a case study has been conducted starting with a mapping of the service offer of the company involved. With this objective, the paper is organized as follow. Section 2 introduces the concept of PSS, unveiling the issues and hurdles occurring during the companies switch from being a product manufacturer to become a product-service integrated provider and proposing the theoretical framework to conduct this research. Then, section 3 reports a detailed description of the adopted methodology. Formerly the used criteria in the case study approach are reported, then an introduction of the assessed company is given. Section 4 explains the results of the study, showing the outputs of the coding analysis, and Section 5 is dedicated to their discussion. Finally, Section 6 concludes the paper, triangulating results with theory and providing further researches and limitations.

\section{The servitization issues for manufacturers}

Companies are beginning to consciously realizing the importance of the servitization phenomenon [5], but they still have to prepare themselves in effectively designing integrated PSSs, complex systems made of product and service components and supported by suitable infrastructures and networks. Goedkoop et al. gave the first formal definition of PSS in 1999. Along the time, different definitions confirmed that PSSs are made to pursue industrial competitiveness, customer satisfaction and sustainable development [15]: as stated by [16], PSS represents a new business model [17] enabling firms to generate new sources of added value and competitiveness, empowering the relationship with customers through customized, innovative and longlasting integrated solutions. There is, however, an open issue on how to detect the real customer demand and how to convert it from an intangible to a tangible dimension [16] to exploit the service offer potential. [7] explained the dynamic of this slow process by three sequential hurdles to be overcome in making such a transition. First, firms might not believe in the economic potential of the service component for their product. Second, although a firm might realize the service market potential, it may decide that providing services is beyond the scope of their competencies. Finally, a firm might realize the service market potential, decide to enter that market but fail in deploying a successful service strategy. Indeed, transitioning from product manufacturer into service provider constitutes a significant managerial challenge. Services require organizational principles, structures and processes new to the product manufacturer: the need of new capabilities, metrics and incentives highlights the shift on the business model changes from transaction to relationship-based. Developing this new set of capabilities necessarily diverts financial and managerial resources from manufacturing and new product development, the traditional sources of competitive advantage for the organization. Related to this, [7] revealed some hurdles for manufacturers to move into 
services, specifically the evaluation of the Installed Base (IB) service potential and the extent to which a firm should enter the service market. Just as product and market attributes determine the profitability potential from the IB, they believe that organizational attributes dictate the extent to which a firm should move along the product-service continuum. In this regard, [19] identified and structured five main tactics for PSS implementation: contracts, marketing, network, product and service design, and sustainability. Each of these tactics has been declined in several particular aspects per each PSS business model category (product, use or result oriented). However, the relationship between PSS business models and these five tactics deserves further investigation, since internal and external organizational conditions can influence it. Indeed, due to the high complexity, if managed wrongly, these possible heterogeneous factors occurring during the servitization path can often lead manufacturers to fail, making them fall in the service paradox [10], [20]. Furthermore, [21] defined three possible service growth trajectories in system suppliers, based on how much manufacturers infuse higher levels of services in their offerings: (1) availability provider, those who promise to achieve availability offering service activities during the system lifecycle in an use-oriented, customized, relational and output-based way; (2) performance provider, similar to project-based sales and requiring a major offer differentiation; and (3) 'industrializer', standardizing previously customized solutions to enable repeatability and scalability. They also assumed that firms need to keep balanced business expansion and standardization activities but also to manage the co-existence of different system supplier roles. Summing up the contributions from literature about such a complicated transition, in Table 1 are reported the elements identified by the authors as relevant to understand how to enter the servitization effectively, supporting to detect and keep into consideration what can foster and hinder such pursuit. These elements, constituting a theoretical framework, have been used to build the protocol to analyze Company A: both the internal and external factors, faced during their approaching to servitization, were detected to exploit their offer under a service perspective.

Table 1 Theoretical framework: elements to effectively assess servitization

\begin{tabular}{|l|l|l|}
\hline & Context & $\begin{array}{l}\text { Elements to be investigated to pursue servitiza- } \\
\text { tion }\end{array}$ \\
\hline 1 & Customer & the type of customers and their needs [16] \\
\hline 2 & $\begin{array}{l}\text { (AS-IS) } \\
\text { offer provided }\end{array}$ & $\begin{array}{l}\text { the type of offer provided by the company: what is } \\
\text { provided to satisfy the customer needs so far and how } \\
\text { (through which kind of revenue stream) [7] [21] }\end{array}$ \\
\hline 3 & $\begin{array}{l}\text { (TO BE) Product/In- } \\
\text { stalled Base potential } \\
\text { service offer }\end{array}$ & $\begin{array}{l}\text { the potential service offer that can be implemented } \\
\text { based on the products provided, to satisfy the unful- } \\
\text { filled customer needs [7] [21] }\end{array}$ \\
\hline 4 & $\begin{array}{l}\text { Knowledge and cultural } \\
\text { aspects }\end{array}$ & $\begin{array}{l}\text { the internal and external processes needing to be im- } \\
\text { proved to foster a cultural servitization shift in the } \\
\text { company [19] [21] }\end{array}$ \\
\hline
\end{tabular}




\section{The case study: the methodology and the company}

In this chapter, formerly a detailed description of the used methodology is reported. Then, the company assessed in the case study is introduced, and its current service offer is mapped. Then, the framework defined in Table 1 were used to build the protocol to conduct the case study and to obtain the results reported in section 4 .

In order to investigate the transition leading the integration of services into the product offering, an explanatory case study has been conducted: it included semistructured interviews to gather data and content analysis to achieve multifaceted information [22], [23] through a hierarchic approach. A list of topics to be investigated in the interview protocol were the starting point in coding analysis to detect variables, categories and labels [24]. The first step has been the definition of the unit of analysis on the basis of the primary aim of the research: the choice fell on Company A Climate Business Unit (BU). The case study approach used is indeed a holistic single-case design approach [22]. Through content analysis, first the main categories were identified, condensed, abstracted and labelled with codes, then patterns were traced: eight main categories were founded and linked together. Even though three interviews were conducted in the different BU of the same company, this paper describes only the Climate BU case, representing a particular context in Company A since it is the only division in the company providing a complete final solution to customers.

Case selection is a complex matter [25]: Company A, an Italian company founded in the early Seventies, has been chosen. The strategy of focusing on technology, quality and innovation - regarding both process and product - allows Company A to achieve a significant role in the world market of Refrigeration, Air Conditioning and Air Humidification and to become a specialist in the development of control systems. The company has two main divisions: HVAC (Heating, Ventilation, Air-Conditioning) and REF (Refrigeration), involving different Original Equipment Manufacturers (OEMs), Dealers and Projects. One of the main issues of the company is represented by a weak value proposition in the service context lacking a structured service design and development process, intended for both its direct customers and the final users of the proposed solutions. Indeed, Company A service offer is limited to commissioning, installation assistance to OEMs, corrective maintenance (mainly towards OEMs), training to OEMs and branches and spare parts provision. The main issue for Company $\mathrm{A}$ is due to their focus on the development of the physical product against the need and will of developing new PSSs, creating a bundle of existing products and add new services.

\section{$4 \quad$ Results}

The preliminary result from the interview is an AS-IS analysis of Company A and of its offer in terms of products, services and PSS/solutions, , with a particular focus on the HVAC Business Unit (BU): this part is useful to realize if it already develops PSSs according to the models proposed by [16]. The division deals with different technologies for humidifiers and control systems, being able to deliver products for different 
types of applications: industrial environments, process industries, clean rooms, conservation and wellness. In this division different typologies of customers are involved: wholesalers $(32 \%)$, contractors/installers (22\%), affiliate/importers (19\%), system integrators $(9 \%)$, distributors $(8 \%)$ and others actors $(10 \%)$ placed in the value chain between OEMs and the final users. Regarding services, while for Air Conditioning and Refrigerator products, generally, the OEMs provide services to the final user since Company A produces only a part of the final product (air condition and refrigeration control system). On the other hand, for Humidifiers, maintenance, installation and commissioning are either mainly provided by the installers or outsourced to three assistance centers in Italy (which are not exclusive for Company A business). Indeed, the service revenue in this division is only the $2 \%$ of the total (mainly coming from commissioning) while spare parts count for the $35 \%$ of the total division profit. In particular, on the humidifiers market, the company provides only two services to its customers. As illustrated in Figure 1, the proposed PSS offer in this division corresponds to product-oriented PSS, more specifically either advice and consultancy or product related services. More precisely, the first is given by Company A's HVAC BU Project and Dealers to installers regarding advice and consultancy to give them the useful information to correctly install their different products in the several contexts they are called to be used. The other service is instead delivered by installers to final users and consists in the practical installation of the solution in the plant of the customer. Furthermore, it is very rare to have the direct selling of the product to the final user: in this case, indeed, Company A's HVAC BU OEM provides the products to OEMs which are then in charge of the selling to the final users. Starting by this assessment, the next step of the analysis deals with evaluating which are the elements that could affect, positively or negatively, Company A in moving towards servitization: the interview allowed the authors to detect which are considered by the interviewee the enabling capabilities of developing service integrated solutions and of enhancing PSS offering in a systematic way.

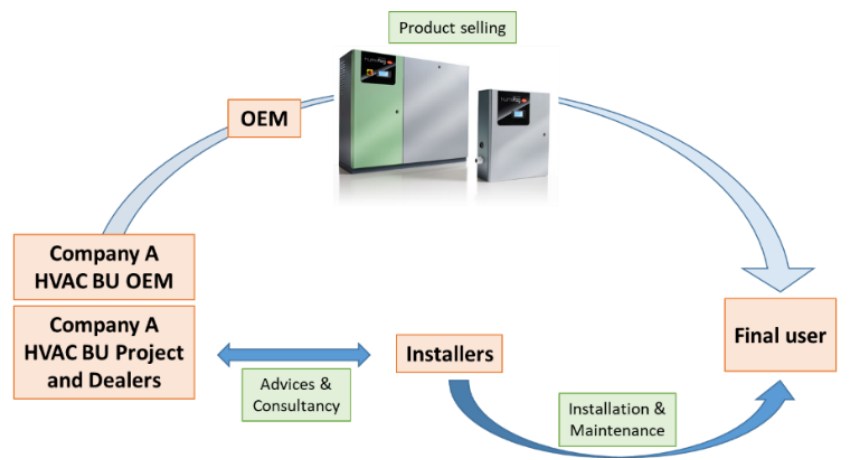

Figure 1. Company A - HVAC BU (for humidifiers) AS-IS product oriented PSS model

The conducted content analysis brought to several results: coding allowed to detect some hidden concepts (Table 2) and to identify positive and negative patterns and relations among them (Figure 2). The analysis started from the four main contexts of the theoretical framework of Table 1, which have been reported in the first column of Table 2 to be linked to the different coding dimensions detected. 
Table 2 Coding results: categories and codes

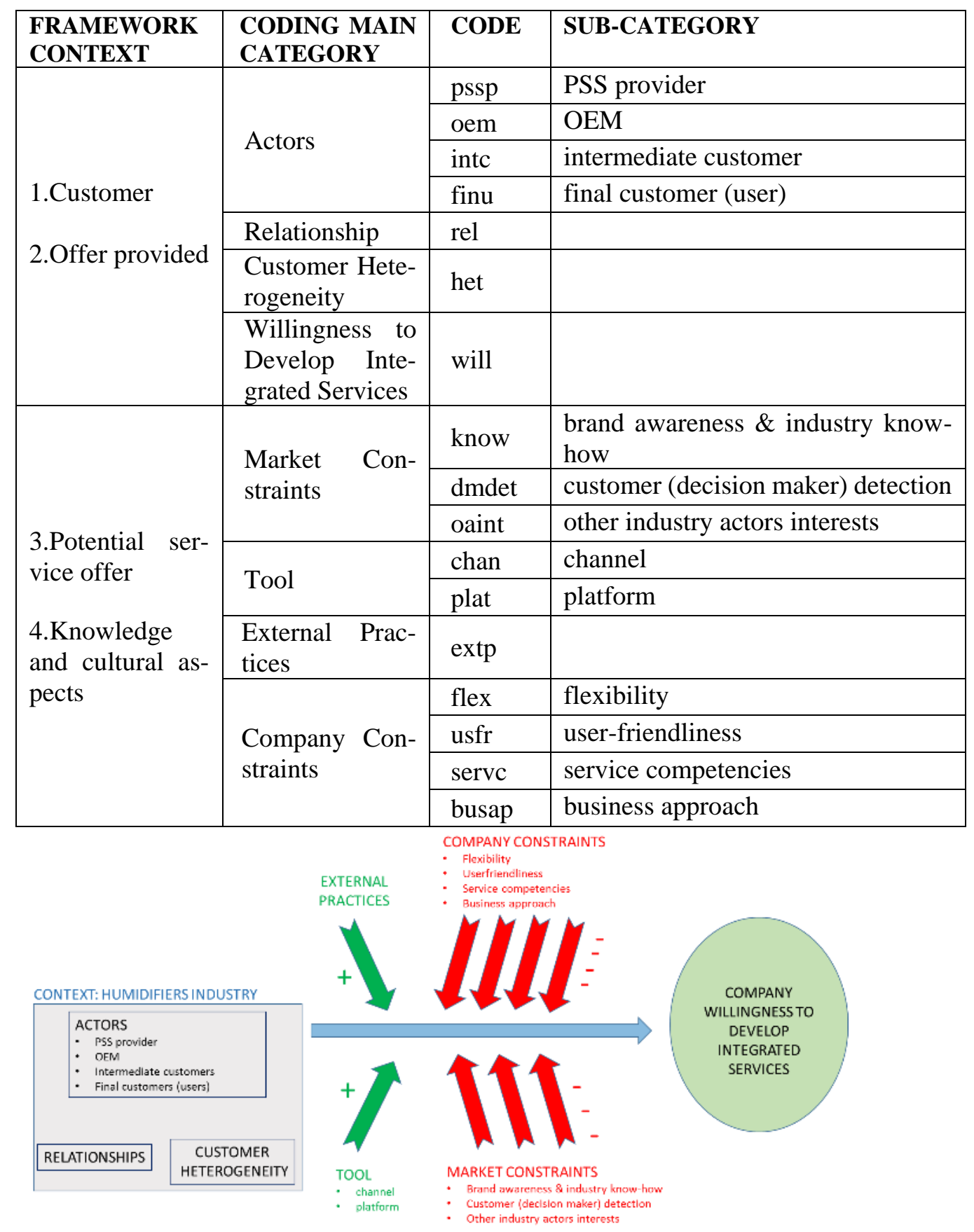

Figure 2. Patterns: relation among the main coded categories 
Table 2 and Figure 2 show coding results: the humidifiers context is characterized by an extensive heterogeneity of customers, which brought the actors to establish several types of strategic relationships. Indeed, product and market attributes, which determine the profitability potential from the IB [7], enabled Company A to act as an availability provider [21]. Also, the company demonstrates a good willingness to develop enhanced integrated services to be included in its offer. However, positive and negative elements were detected, the company's organizational attributes, affecting its attempt to act in that direction [7]. In this specific case, to enhance its organizational setting, on one hand, the company identified some examples among its competitors and other industries, to be used as best practices, and also some tools, mainly communication channels and development platform, which could allow it to better understand the customer needs and to satisfy them more suitably [26], [27]. On the other hand, it knows that different hurdles, either at the company or market/industry level, impede them to move in a direct way to the so-called performance provider trajectory [21]. Internally they need more flexibility, user-friendliness, service competencies and more B2C oriented approach; externally they must, first of all, detect the real customer they look at (with their characteristics and the amount of the relative business), coping with improving the brand awareness \& know-how of customers about the industry complexity and also facing competitors and other actors (mainly intermediate customers as installers) interests. In this situation, the creation and introduction of new services thought exclusively for the final users and able to directly reach them, could be useful. For example, to exploit the spare parts business, Company A could install on the product a control system able to suggest in advance the need of a spare part and to send the order directly to them. This would simplify the ordering process, avoid the product failure and then increase the customer satisfaction. Since in this market the final customer is not the decision maker, but the installers select the system to be installed for each application, the company currently works to strengthen the relationship with these actors. In addition to this, since a large amount of different applications characterizes this BU, the company needs a higher level of flexibility in its solutions. However, a "plug and play" solution able to adapt to the different applications is still missing. It would support the company to have a better understanding of the customer needs and a market segmentation based on it: how many types of users could be interested in buying such solutions, which are the communication means and channels needed to reach the different users, how to understand what is the real value for each of them and what they need to know about the product before the purchasing. The "plug and play solution" would support Company A to move towards the 'industrializer' trajectory [21], balancing business expansion and standardization activities to enable repeatability and scalability.

\section{Discussion}

The pattern traced in the results of this paper through the coding analysis furtherly raises some open issues already reported in the literature. After having ascertained that Company $\mathrm{A}$ is at the beginning of its route in the product-service continuum, the case study confirmed that the first steps to be fulfilled are consistent with what reported by [7], i.e. 
the consolidation of the product-related service offering and the entrance to the IB service market. Given that the product and the market attributes determine the profitability potential from the IB [7], the main issue for the company resulted to be the evaluation of the potential market and the understanding of which channel should be used to penetrate it. To this purpose Company A is willing to implement an analysis of how users approach the humidification market and of what they try to search on the web when they want to solve their problems. Through a consistent assessment of data, that could be the used keywords on research engines by customers and the feedback coming from the users, the potential market could be detected and characterized and thus their needs better defined and satisfied. These hurdles contribute to make also Company A route in the product-service continuum relatively relaxed and careful [7]. This happens because even though organizations consider services an important component of the consumer satisfaction indicators, firms often realize that providing services is beyond the scope of their competencies and their business approach. The interviewee stated indeed that, also due to the company traditional B2B setting, they do not own the required competencies to develop services internally even if they strongly desire it. PSS design and development is, in fact, a process that requires a considerable effort in terms of several backgrounds, like technical specialization, business organization, data and knowledge management. New organizational principles, structures and processes are required. Company $\mathrm{A}$ in this specific case is thinking to remedy to this establishing some new partnerships that could improve the offered service level: however, this could not be enough. To improve the delivery of services, the creation of a single organizational unit, identifying the profit opportunity within the service arena, and the setting up of the structures and processes to exploit it would be required. This is what the analyzed company desires to implement, not hiding in the meanwhile the internal and external constraints it is already coping with. [28] explained how a company acting in the same humidification industry, Danfoss A/S, created a dedicated business unit to offer services and move up the supply chain from its position of the component supplier, creating a stronger and more direct relationship with its customers. The importance of the business model from transaction to relationship-based is strategic.

\section{Conclusions and further researches}

This paper proposed a theoretical framework to understand what can affect companies during their transition from a product-centric approach to a service integrated one. To do this, first the offer of a company has been mapped according to the eight PSS archetypes. Related to this, the open issue reported by [16] is confirmed: even if the importance of services is progressively growing, also in this case, the company has several difficulties in identifying the real customer demand and convert it from an intangible to a tangible dimension. The content analysis supported in uncovering the solution to this problem: the use of new tools, i.e. the exploitation of the extensive amount of data available on the new communication channels to come up with a consistent segmentation of the market, and the adoption of a platform for integrated service design. About the methodology, a theoretical framework, based on the analysis of the literature, was built. The case study presented in this paper was conducted to conduct the framework verification and triangulate the hints coming from the literature with practical findings, 
confirming that an effective service orientation assessment of a company needs to start from a focus on the type of customers, of the offer and of the revenue stream generated (composing part of the theoretical framework proposed in Table 1). Moreover, the content analysis suggested that different elements deserve attention along the servitization path: the product and the industry characteristics, the customer heterogeneity and the relationships along the value chain can affect the potential from the IB. Instead, market (e.g. brand awareness \& industry know-how, customer detection, industry actors interests) and company (e.g. flexibility, user-friendliness, service competencies, business approach) constraints, together with external practices and supporting tools (channel, platform), can affect companies capacity to internally modify their organization and pursue a more service-oriented trajectory.

Finally, some limitations can be highlighted for this research. The paper presents only one of the BU of the company of enhancing a servitization strategy. Further researches will be conducted: first, also the other two interviews already performed in the company about claim management and product monitoring platform could be included in the coding analysis, getting a comparison among different contexts. Then, on the basis of the next results, the unit of analysis could be enlarged to other companies and industries to obtain complete information about the service infusion phenomenon and to understand how much the context could affect its evolution. Moreover, while this work is only limited to map a company service offering according to the PSS archetypes, a structured approach can be defined and proposed to enable the assessment of the company service orientation to move along the product-service continuum, starting from the framework proposed and the results obtained with this case.

\section{Acknowledgements}

This work was funded by the European Commission through Diversity Project, GA 636692, under the H2020 program.

\section{References}

[1] V. R. Fuchs, "The service economy. National Bureau of Economic Research,” 1968.

[2] L. Santamaría, M. Jesú S Nieto, and I. Miles, "Service innovation in manufacturing firms: Evidence from Spain."

[3] S. Vandermerwe and J. Rada, "Servitization of business: Adding value by adding services," Eur. Manag. J., vol. 6, no. 4, pp. 314-324, 1988.

[4] T. S. Baines et al., "State-of-the-art in product-service systems," Proc. Inst. Mech. Eng. Part B J. Eng. Manuf., vol. 221, no. 10, pp. 1543-1552, Jan. 2007.

[5] F. Jacob and W. Ulaga, "The transition from product to service in business markets: An agenda for academic inquiry,” Ind. Mark. Manag., vol. 37, no. 3, pp. 247-253, 2008.

[6] W. Ulaga and W. J. Reinartz, "Hybrid Offerings: How Manufacturing Firms Combine Goods and Services Successfully," J. Mark., vol. 75, no. November, pp. 5-23, 2011.

[7] R. Oliva and R. Kallenberg, "Managing the transition from products to services," Int. J. Serv. Ind. Manag., vol. 14, no. 2, 2003.

[8] C. Kowalkowski, D. Kindström, T. B. Alejandro, S. Brege, and S. Biggemann, "Service 
infusion as agile incrementalism in action," J. Bus. Res., vol. 65, no. 6, pp. 765-772, 2012.

[9] A. L. Ostrom et al., "Moving Forward and Making a Difference: Research Priorities for the Science of Service," J. Serv. Res., vol. 13, no. 1, pp. 4-36, 2010.

[10] S. Brax, "A manufacturer becoming service provider - challenges and a paradox," Manag. Serv. Qual. An Int. J., vol. 15, no. 2, pp. 142-155, Apr. 2005.

[11] A. P. B. Barquet, M. G. de Oliveira, C. R. Amigo, V. P. Cunha, and H. Rozenfeld, "Employing the business model concept to support the adoption of product-service systems (PSS)," Ind. Mark. Manag., vol. 42, no. 5, pp. 693-704, 2013.

[12] M. E. Porter and J. E. Heppelmann, "How Smart, Connected Products Are Transforming Competition," Harv. Bus. Rev., no. November, 2014.

[13] R. U. Ayres, "Peer reviewed: toward a zero-emissions economy.," Environ. Sci. Technol., vol. 32, p. 366A-7A, 1998

[14] M. J. Goedkoop, C. J. G. Van Halen, H. R. M. te Riele, and P. J. M. Rommens, "Product service systems, ecological and economic basics. Report for Dutch Ministries of environment (VROM) and economic affairs (EZ),” vol. 36, no. 1, pp. 1-122, 1999.

[15] A. Tukker and U. Tischner, "Product-services as a research field: past, present and future. Reflections from a decade of research," J. Clean. Prod., vol. 14, no. 17, pp. 1552-1556, Jan. 2006.

[16] A. Tukker, "Eight types of product-service system: Eight ways to sustainability? Experiences from suspronet," Bus. Strateg. Environ., vol. 13, no. 4, pp. 246-260, 2004.

[17] O. Zaring et al., "Creating eco-efficient producer services," 2001.

[18] A. Tukker and C. Van Halen, "Innovation scan for product service systems," 2003.

[19] W. Reim, V. Parida, and D. Örtqvist, "Product-Service Systems (PSS) business models and tactics - a systematic literature review," J. Clean. Prod., Jul. 2014.

[20] H. Gebauer, E. Fleisch, and T. Friedli, "Overcoming the Service Paradox in Manufacturing Companies," Eur. Manag. J., vol. 23, no. 1, pp. 14-26, Feb. 2005.

[21] C. Kowalkowski, C. Windahl, D. Kindström, and H. Gebauer, "What service transition? Rethinking established assumptions about manufacturers' service-led growth strategies," Ind. Mark. Manag., vol. 45, no. 1, pp. 59-69, 2015.

[22] R. K. Yin, Case Study Research Design and Methods, 4th ed., vol. 5. 2009.

[23] K. M. Eisenhardt, "Building Theories from Case Study Research.," Academy of Management Review, vol. 14, no. 4. pp. 532-550, 1989.

[24] B. L. Berg, Qualitative research methods for the social sciences, vol. Seventh Ed. 2001.

[25] M. Henn, M. Weinstein, and N. Foard, "A short introduction to Social Research," Soc. Res. (New. York)., p. 296, 2006.

[26] C. Sassanelli, S. Terzi, G. Pezzotta, and M. Rossi, "How Lean Thinking affects Product Service Systems Development Process," in XX Summer School Francesco Turco 2015 - Operational Excellence Experiences, 2015, pp. 97-104.

[27] C. Sassanelli, G. Pezzotta, M. Rossi, S. Terzi, and S. Cavalieri, "Towards a Lean Product Service Systems (PSS) Design: State of the Art, Opportunities and Challenges," in Procedia CIRP, 2015, vol. 30, pp. 191-196.

[28] A. R. Tan, D. Matzen, T. C. McAloone, and S. Evans, "Strategies for designing and developing services for manufacturing firms," CIRP J. Manuf. Sci. Technol., vol. 3, no. 2, pp. 90-97, 2010. 